\title{
PENGEMBANGAN KREATIVITAS ANAK USIA DINI MELALUI MEDIA PEMBELAJARAN TEKNIK INFORMASI DAN KOMUNIKASI (TIK)
}

\author{
Heri Hidayat \\ Universitas Islam Negeri Sunan Gunung Djati Bandung \\ herihidayat@uinsgd.ac.id \\ Nanda Aulia \\ Universitas Islam Negeri Sunan Gunung Djati Bandung \\ nandaau1045@gmail.com \\ Nita Tania \\ Universitas Islam Negeri Sunan Gunung Djati Bandung \\ nitat9494@gmail.com \\ Tasya Salsabila G \\ Universitas Islam Negeri Sunan Gunung Djati Bandung \\ tasyasalsabila06@gmail.com
}

\begin{abstract}
Abstrak
Penulisan jurnal ini bertujuan untuk mengumpulkan data- data hasil penelitian yang telah dilakukan tentang Pengembangan Kreativitas Anak Usia Dini melalui Media Pembelajaran Teknik Informasi dan Komunikasi (TIK). Penulisan jurnal ini di latar belakangi untuk mengetahui apakah melalui media pembelajaran TIK dapat membantu pengembangan kreativitas anak usia dini. Data yang dikumpulkan melalui metode pustaka dengan mengmpulkan jurnal- jurnal dari internet. Hasil penelitian menunjukan bahwa pengembangan kreativitas anak usia dini dapat di pengaruhi oleh media pembelajaran Teknik Informasi dan Komunikasi (TIK). Hal tersebut dapat dibuktikan dari hasil penelitian dari beberapa jurnal yang kami ambil sebagai data-data dan sumber. Kata Kunci: Anak Usia Dini, Kreativitas, Media Pembelajaran TIK

Abstract

Writing this journal aims to collect data on the results of research that has been done on Early Childhood Creativity Development through Information and Communication Technique (ICT) Learning Media. This journal is written in the background to find out whether through ICT learning media can help develop early childhood creativity. The data collected through the library method by collecting journals from the internet. The results showed that the development of early childhood creativity can be influenced by Information and Communication Engineering (ICT) learning media. This can be proven from the results of research from several journals that we take as data and sources. Keywords: Early Childhood, Creativity, ICT Learning Media
\end{abstract}




\begin{tabular}{|c|c|c|}
\hline \multicolumn{3}{|c|}{ Jurnal Warna : Jurnal Pendidikan Dan Pembelajaran Anak Usia dini. } \\
Maret 2021. Vol 06. No. 01
\end{tabular}

\section{Pendahuluan}

Bangsa Indonesia kini memasuki abad ke 21 yang mana mengalami kemajuan perkembangan ilmu pengetahuan dan teknologi yang sangat pesat, hal ini ditandai dengan adanya penyebaran informasi dan komunikasi yang sangat pesat dalam setiap kehidupan termasuk dalam dunia pendidikan khususnya pendidikan anak usia dini. Masyarakat khususnya orang tua yang memiliki anak usia dini tidak lepas dari penggunaan teknologi seperti smartphone, televisi, ataupun gadget. Menurut Zaini \& Soenarto (2019:258) dalam jurnal Pemanfaatan Teknologi Dalam Pendidikan Anak Usia Dini yang ditulis oleh Luthfatun Nisa mengatakan penggunaan smartphone, televisi, ataupun gadget dikalangan anak-anak bukan hal baru, bahkan $90 \%$ orangtua menyampaikan bahwa gadget yang banyak digunakan oleh anak mereka dalam rentang usia 4-6 tahun adalah smartphone.

Anak usia dini merupakan usia di masa emas atau golden age yang sangat perlu mendapatkan bimbingan dan memiliki potensial untuk melatih dan mengembangkan berbagai potensi kecerdasan yang dimilikinya terutama dalam mengembangkan ilmu pengetahuan dan teknologi yang sangat pesat saat ini. Selain dapat digunakan dalam kehidupan sehari - hari teknologi juga dapat banyak dimanfaatkan untuk mendukung proses pembelajaran khususnya di pendidikan anak usia dini. Menurut Nisa (2012:94) dalam jurnal Pengaruh Pembelajaran Melalui Media Teknologi Informasi Komunikasi (TIK) Dan Media Cetak Terhadap Kreativitas Anak Usia Dini Di TK Aminah Hamdi. Kec. Medan Marelan Kota Medan yang ditulis oleh Tuti Syahyuni teknologi dapat dimanfaatkan sebagai media dalam mengenalkan konsep bilangan, dan penalaran pada anak. Sebenarnya, terdapat banyak potensi dari teknologi yang dapat memberikan manfaat atau bahkan bahaya bagi anak (Keengwe dan Onchwari: 2008). Namun semua itu tergantung lingkungan dalam memberikan dan mengembangkan aktifitas yang dilakukan anak usia dini melalui teknologi secara tepat. Pengembangan kreativitas sangat penting bagi diri seseorang karena dengan kreativitas dapat meningkatkan prestasi akademik.

Kreativitas adalah hasil interaksi antara individu dan lingkungannya, kemampuan untuk membuat kombinasi baru, berdasarkan data, informasi, atau unsur-unur yang sudah ada atau dikenal sebelumnya, yaitu semua pengalaman dan pengetahuan yang telah diperoleh seseorang selama hidupnya baik itu di lingkungan sekolah, keluarga, maupun 


\begin{tabular}{|c|c|c|}
\hline \multicolumn{3}{|c|}{ Jurnal Warna : Jurnal Pendidikan Dan Pembelajaran Anak Usia dini. } \\
Maret 2021. Vol 06. No. 01 \\
\hline Received: September 2020 & Accepted: Januari 2021 & Published: Maret 2021 \\
\hline & Article DOI: 10.24903/jw.v4i2.620 \\
\hline
\end{tabular}

dari lingkungan masyarakat (fakhryani, 2016:195). Kreativitas pada anak usia dini adalah kemampuan untuk menghasilkan pemikiran-pemikiran yang asli, tidak biasa, dan sangat fleksibel dalam merespon dan mengembangkan pemikiran dan aktivitas (fakhryani, 2016:197). Dalam pengembangan kreativitas anak usia dini tidak terlepas dari dorongan orang di sekitarnya, baik itu orang tua, guru dan lingkungan anak. Oleh karena itu ketika proses pengembangan kreativitas anak usia dini dapat diberikan stimulus melalui media pembelajaran agar anak mudah untuk mengembangkan kreativitas pada dirinya

Media pembelajaran sangat penting dalam proses memberikan stimulus kepada anak dalam meningkatkan kreativitas anak. Sebagaimana menurut Munadi (2008) yang dikutip oleh Nurhafizah (2018) mendefinisikan media pembelajaran sebagai segala sesuatu yang dapat menyampaikan dan menyalurkan pesan dari sumber secara terencana sehingga tercipta lingkungan belajar yang kondusif dimana penerimanya dapat melakukan proses belajar secara efisien dan efektif. Media pembelajaran berfungsi bukan hanya sebagai sarana untuk membuat pembelajaran yang menyenangkan, tetapi juga membantu anak memahami sesuatu yang bersifat abstrak (Nurhafizah,
2018:4). Media pembelajaran yang dapat dilakukan untuk mengembangakn kreativitas anak usia dini di era digital yaitu seorang pendidik atau peserta didik dapat menggunakan media pembelajaran Teknologi informasi dan komunikasi (TIK).

Proses belajar memanfaatkan sumber belajar yang bersifat elektronik, dan juga komputer tidak selalu harus terhubung dengan internet (Dewi Salma Prawiradiulaga, dkk, 2013:2). Menurut Sodiq Anshori dalam jurnal Pemanfaatan TIK Sebagai Sumber Dan Media Pembelajaran Di Sekolah, mengatakan bahwa belajar berbasis jaringan (webbassed learning), merupakan proses belajar yang menggunakan sumber dan media internet untuk memudahkan proses belajar dan mengajar. Sedangkan learning atau mobile learning adalah pola webbassed learning yang dapat diakses melalui produk computer dalam ukuran yang lebih kecil, ringan dan mudah dibawa, seperti telepon seluler atau tablet.

Teknologi informasi dan komunikasi (TIK) merupakan alat yang dapat membantu dalam proses pembelajaran, dimana dalam penggunaan media TIK dapat dilakukan untuk pencarian data pengembangan media dalam pembelajaran supaya proses pembelajaran akan lebih baik. (Nur \& Febrialismanto, 2020:30). Pembelajaran 


\begin{tabular}{|c|c|c|}
\hline \multicolumn{3}{|c|}{ Jurnal Warna : Jurnal Pendidikan Dan Pembelajaran Anak Usia dini. } \\
& Maret 2021. Vol 06. No. 01 \\
\hline Received: September 2020 & Accepted: Januari 2021 & Published: Maret 2021 \\
\hline & Article DOI: $10.24903 / j w . v 4 i 2.620$ \\
\hline
\end{tabular}

dengan menggunakan teknologi memberi kesempatan dan peluang bagi pendidik juga peserta didik, bagi pendidik dapat meningkatkan dan mengembangkan kompetensinya terutama kompetensi paedagogik dan profesional. Penggunaan teknologi dalam pembelajaran diharapkan dapat menjadi solusi dalam mengatasi permasalahan anak dalam proses pembelajaran di era digital. Peserta didik juga dapat menggunakan perangkat teknologi informasi dan komunikasi untuk mengembangkan kreativitas anak yang meliputi eksplorasi, mencari, menganalisa, dan saling tukar informasi secara efisien dan efektif.

Atas dasar hal tersebut di atas, maka peneliti berkeinginan mengangkat permasalahan tersebut dalam penelitian berjudul "Pengembangan Kreativitas Anak Usia Dini Melalui Media Pembelajaran Teknik Informasi Dan Komunikasi (TIK)".

\section{Metode Penelitian}

Penelitian ini menggunakan metode pustaka (Library Research). Metode Pustaka merupakan serangkaian metode yang mempelajari suatu referensi untuk mendapatkan landasan teori dari suatu permasalahan yang sedang diteliti. Metode pustaka biasanya dijadikan sebagai suatu cara dalam pengumpulan sebuah data dengan membaca, catatan dan bersumber dari buku atau perpustakaan .

Menurut Sutrisno Hadi (1990) dalam jurnal Penelitian Kepustakaan yang ditulis oleh Nursapia Harahap, beliau mengatakan disebut penelitian pustaka karena sumber-sumber, bahan- bahan yang diperlukan untuk menyelesaikan penelitian berasal dari perpustakaan berupa buku, ensiklopedi, kamus, jurnal, dokumen, artikel, majalah dan lain sebagainya

Menurut Zed (2003:4-5) dalam jurnal Community Of Practitioners : Solusi Alternatif Berbagi Pengetahuan Antar Pustakawan yang ditulis oleh Supriyadi, beliau mengatakan dalam penelitian menggunakan metode pustaka terdapat 4 ciri utama yang harus diperhatikan : Pertama, peneliti harus berhadapan langsung denga buku ( nash ) atau berupa angka, bukan dari suatu data yang didapatkan secara langsung dilapangan. Kedua, data pustaka merupakan data yang siap pakai, sehingga peneliti tidak perlu meneliti dilapangan secara langsung, karena peneliti sudah mendapatkan data dari sumber perpustakaan. Ketiga, pada dasarnya data pustaka merupakan data sekunder, yang artinya peneliti mendapatkan data bukan dari sumber pertama dilapangan melainkan dari sumber atau tangan kedua. 


\begin{tabular}{|c|c|c|}
\hline \multicolumn{3}{|c|}{ Jurnal Warna : Jurnal Pendidikan Dan Pembelajaran Anak Usia dini. } \\
Maret 2021. Vol 06. No. 01 \\
\hline Received: September 2020 & Accepted: Januari 2021 & Published: Maret 2021 \\
\hline & Article DOI: 10.24903/jw.v4i2.620 \\
\hline
\end{tabular}

Keempat, data pustaka tidak dibatasi oleh ruang dan waktu.

Maka pengumpulan data menggunakan metode pustaka penelitian dilakukan dengan menelaah dan mengekplorasi beberapa buku, dokumendokumen ( baik yang berupa cetak atau elektronik ), jurnal, artikel serta sumbersumber data dan informasi yang lainnya yang dianggap dapat dipercaya dalam memenuhi data penelitian.

\section{Hasil dan Pembahasan}

Hasil dan pembahasan penelitian ini diperoleh dari kajian pustaka dari internet, jurnal, dan sumber-sumber data lainnya. Berdasarkan data yang telah kami ambil dari 3 sumber jurnal dari internet berikut jurnal yang peneliti analisis ; 1) Syahyuni Tuti. (2010). “ Pengaruh Pembelajaran Melalui Media Teknologi Informasi Komunikasi (TIK) Dan Media Cetak Terhadap Kreativitas Anak Usia Dini Di TK Aminah Hamdi. Kec. Medan Marelan Kota Medan”. Medan: Program Studi Magister Psikologi Universitas Medan Area. Vol 5. No 2 ; 2) Nadar Wahyuni, (2020). “ Implementasi Pembelajaran Berbasis Teknologi Informasi (Ti) Di Taman Kanak-Kanak Bunga Bangsa Islamic School Bekasi”. Jakarta: Sekolah Tinggi Keguruan dan Ilmu Pendidikan Kusuma Negara,
Indonesia; 3) Hartawan I Made. (2020). "Peningkatan Kreativitas Pada Anak Usia Dini Melalui Pembelajaran Berbasis Tik Di Tk Tunas Mekar Kecamatan Sukasada Kabupaten Buleleng”. Singaraja: STAHN MPU Kuturan Singaraja. Vol 05. No. 02.

Berikut penjelasan mengenai hasil dan pembahasan dari kajian pustaka pada 3 jurnal diatas pada jurnal pertama tentang Pengaruh Pembelajaran Melalui Media Teknologi Informasi Komunikasi (TIK) dan Media Cetak Terhadap Kreativitas Anak Usia Dini Di TK Aminah Hamdi. Kec. Medan Marelan Kota Medan yang tulis oleh Tuti Syahyuni menjelaskan bahwa penggunaan media TIK dalam pembelajaran anak usia terdapat pengaruh terhadap kreativitasnya, hal ini terbukti dari hasil penelitian yang ditunjukkan oleh nilai koefisien $\mathrm{F}=118.088$, nilai signifikansi $0,000(\mathrm{p}<0,005)$. Nilai signifikan $0,000<0,005$. Hal ini berarti Terima Ha. Pengaruh media teknologi sangat berpengaruh pada anak usia dini, mengingat bahwa perkembangan anak usia dini berada dimasa sangat konkret, itu artinya anak diharapkan dapat mempelajari sesuatu secara nyata. Media teknologi yang digunakan di TK tersebut diantaranya berupa video pembelajaran yang berhubungan dengan tema pembelajaran yang sedang dilaksanakan pada hari itu. 


\begin{tabular}{|c|c|c|}
\hline \multicolumn{3}{|c|}{ Jurnal Warna : Jurnal Pendidikan Dan Pembelajaran Anak Usia dini. } \\
Maret 2021. Vol 06. No. 01
\end{tabular}

Pada jurnal kedua tentang Implementasi Pembelajaran Berbasis Teknologi Informasi (TI) Di Taman Kanak-Kanak Bunga Bangsa Islamic School Bekasi yang ditulis oleh Wahyuni Nadar yaitu berdasarkan pencapaian perkembangan yang dikembangkan terutama dalam isi pencapaian perkembangan aspek sosial dan sains yang memasukkan pengetahuan dan keterampilan mengunnakan media teknologi dalam kehidupan sehari-hari. Hal ini sebagaimana berdasarkan dari hasil wawancara dengan kepala sekolah tentang perumusan kurikulum yaitu yayasan juga mengobservasi tingkat pengenalan anak terhadap teknologi yang berada disekitar mereka. Pembahasan hasil pengamatan ini dapat digambarkan dengan diskusi yang interaktif sehingga menghasilkan kreativitas atau pengetahuan yang baru.

Pada jurnal ketiga tentang Peningkatan Kreativitas Pada Anak Usia Dini Melalui Pembelajaran Berbasis Tik Di Tk Tunas Mekar Kecamatan Sukasada Kabupaten Buleleng yang ditulis oleh I Made Hartawan menjelaskan hasil dari presentase yang telah dilakukan maka diperoleh kreativitas anak usia dini melalui pembelajaran berbasis TIK yang dikategorikan baik dari $46,6 \%$ menjadi $79,9 \%$. Salah satu media TIK yang digunakan yaitu Microsoft Pain, dengan Microsoft Pain anak dapat menggambar atau melukis apa saja yang mereka inginkan. Melukis atau menggambar ini merupakan salah satu cara untuk merealisasikan bakat dan kreativitas seni anak. Saat kegiatan belajar mengajar menggunakan pembelajaran berbasis TIK, aktifitas siswa dalam mengikuti pembelajaran juga terlihat semakin meningkat dari rata-rata cukup dan kurang menjadi baik bahkan baik sekali. Demikian juga aktivitas guru semakin meningkat yakni mampu mengelola proses pembelajaran lebih efektif, inovatif, kreatif, dan menyenangkan.

\section{Kesimpulan}

Penelitian ini menggunakan metode pustaka (Library Research) yang menganalisis 3 jurnal dalam internet. Hasil dari analisis yang peneliti lakukan bahwasannya pengembangan kreativitas anak usia dini dapat di pengaruhi oleh media pembelajaran Teknik Informasi dan Komunikasi (TIK).

Sebagaimana pada jurnal pertama dijelaskan bahwa kreativitas anak usia dini dapat dipengauhi oleh media pembelajaran TIK, dimana media tersebut berupa vidio yang diberikan kepada anak dalam proses pembelajaran yang disesuaikan dengan tema. 


\begin{tabular}{|c|c|c|}
\hline \multicolumn{3}{|c|}{ Jurnal Warna : Jurnal Pendidikan Dan Pembelajaran Anak Usia dini. } \\
Maret 2021. Vol 06. No. 01 \\
\hline Received: September 2020 & Accepted: Januari 2021 & Published: Maret 2021 \\
\hline & Article DOI: 10.24903/jw.v4i2.620 \\
\hline
\end{tabular}

Pada jurnal kedua bahwa media TIK juga dapat mempengaruhi kreativitas anak, dimana dengan penerapan teknologi pada peroses pembelajaran anak juga dapat membantu anak dalam proses perkembangannya dalam sosial, kognitif (pengetahuan), dan sains. Sehingga anak akan berfikir kritis dan kreatif dengan adanya implementasi pembelajaran berbasis TIK di taman kanak-kanak (TK).

Selanjutnya pada jurnal kedua menjelaskan bahwa kreativitas anak usia dini dapat dipengaruhi oleh media pembelajaran TIK, dimana salah satu media TIK yang digunakan yaitu Microsoft Pain, dengan Microsoft Pain anak dapat menggambar atau melukis apa saja yang mereka inginkan. Sehingga kreativitas anak dapat meningkat dengan adanya media pembelajaran yang berbasis TIK.

\section{Daftar Pustaka}

Febrialismanto, Nur Hidayatun. (2020). "Hubungan Aktivitas Penggunaan

Teknologi dengan Memilih TIK Untuk Pengembangan Anak Usia Dini". Riau: Universitas Islam Riau. Vol. 3. No 2. Hal.30

Hartawan I Made. (2020). "Peningkatan Kreativitas Pada Anak Usia Dini Melalui Pembelajaran Berbasis Tik Di Tk Tunas Mekar Kecamatan Sukasada Kabupaten Buleleng". Singaraja: STAHN MPU Kuturan Singaraja. Vol 05. No. 02.
Anshori Sodiq." Pemanfaatan Tik Sebagai Sumber Dan Media Pembelajaran di Sekolah ". Jurnal Ilmu Pendidikan Pkn dan Soaial Bidaya. Universitas Terbuka.

Vidya Diana Fakhriyani. (2016). "Pengembangan Kreativitas Anak Usia Dini" Jurnal Pemikiran Penelitian Pendidikan dan Sains.

Madura: Universitas Islam Madura. Hal.193-195

Nisa Luthfatun. (2001). "Pemanfaatan Teknologi Dalam Pendidikan Anak Usia Dini ". Pamekasan: Institut Agama Islam Negeri Madura. Hal.94

Hardiyana Andri.

"Optimalisasi

Pemanfaatan Teknologi Informasi Dan Komunikasi Dalam Pembelajaran Paud".

Nurhafizah. (2018). "Pelatihan Pembuatan Media Pembelajaran Anak Usia Dini Menggunakan Bahan Bekas". Jurnal Pendidikan : Early Chidhood. Universitas Negeri Padang. Vol.2. No.2. Hal.4

Syahyuni Tuti. (2010). “ Pengaruh Pembelajaran Melalui Media Teknologi Informasi Komunikasi (TIK) Dan Media Cetak Terhadap Kreativitas Anak Usia Dini Di TK Aminah Hamdi. Kec. Medan Marelan Kota Medan”. Medan: Program Studi Magister Psikologi Universitas Medan Area.

Nadar Wahyuni, (2020). “ Implementasi Pembelajaran Berbasis Teknologi Informasi (Ti) Di Taman Kanak-Kanak Bunga Bangsa Islamic School Bekasi”. Jakarta: Sekolah Tinggi Keguruan dan Ilmu Pendidikan Kusuma Negara, Indonesia.

Harahap Nursapia, (2004). “ Penelitian Kepustakaan”. Medan: Fakultas Dakwah dan Komunikasi IAIN-SU Medan. 
Jurnal Warna : Jurnal Pendidikan Dan Pembelajaran Anak Usia dini.

\begin{tabular}{|c|c|c|}
\hline \multicolumn{3}{|c|}{ Jurnal Warna: Jurnal Pendidikan Dan Pembelajaran Anak Usia dini. } \\
Maret 2021. Vol 06. No. 01 \\
\hline Received: September 2020 & Accepted: Januari 2021 & Published: Maret 2021 \\
\hline & Article DOI: $10.24903 / j w . v 4 i 2.620$ \\
\hline
\end{tabular}

Supriyadi, (2016). "Community Of

Practitioners : Solusi Alternatif
Berbagi Pengetahuan Antar Pustakawan". Lentera Pustaka. 